\author{
AdAm DobaczewsKi \\ Uniwersytet Mikołaja Kopernika w Toruniu \\ Instytut Językoznawstwa \\ ORCID: 0000-0003-0724-3809
}

\title{
Gramatyka operacyjna vs gramatyka konstrukcji (na przykladzie quasi-tautologii i powtórzeń)
}

\begin{abstract}
A bstrakt: W niniejszym artykule przedmiotem konfrontacji są dwa lingwistyczne podejścia badawcze: tzw. Construction Grammar rozwijana intensywnie w ostatnich latach głównie w językoznawstwie kognitywnym i reprezentowana przez licznych badaczy lingwistyki polskiej, europejskiej, a także światowej oraz mniej znana, autorska propozycja metodologiczna Andrzeja Bogusławskiego (tzw. Operational Grammar, po raz pierwszy wyłożona w artykule z 1978 roku). Na przykładzie opisu wybranych typów konstrukcji powtórzeniowych polszczyzny i kilku innych języków pokazano istotne różnice w efektach zastosowania obu podejść badawczych. Główną tezą jest diagnoza, że w przeciwieństwie do modnej i chętnie uprawianej gramatyki konstrukcji propozycja metodologiczna polskiego lingwisty oparta na zasadniczej idei proporcjonalności w języku daje narzędzia umożliwiające efektywne rozróżnianie w obrębie konstrukcji powtórzeniowych 1) rzeczywistych jednostek operacyjnych danego języka; 2) przewidywalnych i zrozumiałych na ogólnych zasadach konstrukcji z tautologicznie wypełnianymi pozycjami przewidzianymi zasadniczo dla elementów różnych oraz 3) powtórzeń będących wynikiem ogólniejszych, być może ponadjęzykowych reguł działania mownego. Pomimo rozmaitości wielu nurtów gramatyki konstrukcji, wydaje się, że nie dostarcza ona narzędzi pozwalających na właściwe oddzielenie tych trzech różnych co do istoty typów zjawisk tekstowych (a w każdym razie nie wskazuje na to pozostająca pod wpływem CG praktyka badań nad powtórzeniami).
\end{abstract}

Słow a klucze: quasi-tautologia; powtórzenie; gramatyka konstrukcji; gramatyka operacyjna 
1. Zestawienie tytułowych koncepcji opisu języka, to jest „gramatyki operacyjnej” (dalej: $G O$ ) i „gramatyki konstrukcji” (dalej: $C G$ ) może wydawać się przedsięwzięciem, mówiąc oględnie, nieracjonalnym. Po jednej bowiem stronie mamy autorską propozycję metodologiczną Andrzeja Bogusławskiego (por. Bogusławski 1976, 1978), rozwijaną konsekwentnie przez tego badacza i realizowaną przez wąskie grono językoznawców polskich od lat z górą czterdziestu, po drugiej zaś stronie wprawdzie nieco młodszą, ale uprawianą $\mathrm{z}$ rozmachem i rozpowszechnianą szeroko przynajmniej od połowy lat dziewięćdziesiątych, kiedy to ukazuje kluczowa praca Adele Goldberg (por. Goldberg 1995), całą rodzinę koncepcji określanych wspólnym mianem Construction Grammar (por. Hoffmann, Trousdale (red.) 2013), która obecna jest niemal w każdym zakątku lingwistycznego świata. Właśnie ta dysproporcja między $G O$ i $C G$, a w szczególności wielość nurtów w obrębie samej $C G$ sprawia, że porównywanie ich z teoretycznego punktu widzenia na pewno nie jest zadaniem wykonalnym $w$ ramach jednego artykułu.

Nie będzie zatem moim celem tutaj ani prezentacja $G O$ we wszystkich jej szczegółach, ani tym bardziej przedstawienie rozmaitych nurtów $C G$. Tytułowe zestawienie koncepcji ma motywację raczej praktyczną niż teoretyczną (choć od wskazania pewnych różnic w zakresie teorii obu koncepcji nie da się - rzecz jasna - uciec). U podstaw porównania koncepcji $G O$ i $C G$ legła bowiem praktyka badawcza: podczas kilkunastoletniej pracy nad szeroko rozumianymi powtórzeniami, w tym quasi-tautologiami w języku polskim (por. Dobaczewski 2018) i śledzenia w związku z tym przedsięwzięciem stanu badań trudno było znaleźć prace traktujące o powtórzeniach w językach naturalnych, które nie byłyby albo wprost osadzone metodologicznie w którymś z nurtów $C G$, albo przynajmniej nie pozostawały z nią w jakimś wyraźnym związku1.

1 Pewnym wyjątkiem są prace lingwistów rosyjskich na temat „małej składni” („малый синтаксис”) i tzw. frazemów syntaktycznych (por. np. Iomdin 2006, Sannikov 2008, Apresjan et al. 2010), których związek z CG nie jest wprawdzie wyraźny (np. w pracach wyżej przytoczonych nie ma odniesień do literatury nurtu $C G$ ), jednak widać w nich bardzo zbliżony sposób postępowania badawczego (o którym niżej) najprościej można nazwać go ,antyredukcjonistycznym”. Oprócz tego są oczywiście w lingwistyce rosyjskiej prace, w tym również o powtórzeniach, które nawiązują wprost do $C G$ (por. np. Rachilina 2010, Kopotev 2008). 
Zainteresowanie badaczy nurtu $C G$ konstrukcjami repetycyjnymi nie może dziwić. Wszak to właśnie $C G$ od samego początku zwracała uwagę na całostki, które nie miały ustabilizowanego leksykalnie składu (jak frazeologizmy, które bez trudu klasyfikują się jako wielowyrazowe jednostki leksykalne), ale jednocześnie ich sens zdawał się nie być prostą funkcją (żeby nie powiedzieć „sumą”) ich składników. Jest jasne, że konstrukcje powtórzeniowe doskonale spełniają wymogi „,prototypowych" konstrukcji w rozumieniu $C G$.

Istotną zasługą prac nurtu $C G$, jak również wspomnianych w przypisie 1 . prac badaczy rosyjskich, było już samo zwrócenie uwagi na zjawiska językowo-tekstowe, które pozostawały przez lata poza zasięgiem systematycznego opisu: rejestracja leksyki nie mogła ich obejmować z natury rzeczy, ignorowały je także opisy składniowe (zarówno strukturalne, jak i generatywne), które nie przywiązywały, jak wiadomo, nadmiernej wagi do zjawisk marginalnych czy peryferyjnych z punktu widzenia opisu danego języka.

Niewątpliwą zaletą $C G$ jest także pokazanie formalnej niejednorodności budulca językowego - tutaj właśnie kluczową rolę odgrywa termin konstrukcja, czyli coś, co nie musi mieć z góry przewidzianej szaty jednego z tradycyjnie wyodrębnianych poziomów języka (cechy fonologiczne / prozodyczne, segmenty morfologiczne, całe słowa oraz ich układy, a także składniowe wzorce takich układów). Tym samym zaciera się w tym ujęciu granica między leksyką a gramatyką, niestety jednak ten interesujący aspekt najczęściej tonie w głębi ogólniejszych postulatów rozmywania granic między poszczególnymi poziomami języka i „,modułami” jego opisu, charakterystycznych dla współczesnego językoznawstwa kognitywnego.

Prawie dwadzieścia lat przed opublikowaniem przez Goldberg (1995) pierwszej definicji „,konstrukcji” ${ }^{2} \mathrm{w}$ rozumieniu doktryny $C G$ powstaje koncepcja jednostek języka Bogusławskiego (1976) oraz teoria gramatyki operacyjnej tegoż autora (Bogusławski 1978, por. też Bogusławski 1988), wprowadzająca kluczowe pojęcie jednostek-operacji. Rozwijana przez następne lata, ale w swych fundamentach zasadniczo niezmienna koncepcja jednostek języka i gramatyki operacyjnej kładzie nacisk na wyodrębnianie jednostek systemu językowego, rozłącznych w sensie właściwym i zachowujących sy-

2 Por.: ,C is a CONSTRUCTION iff ${ }_{\text {def }} \mathrm{C}$ is a form-meaning pair $<\mathrm{F}_{i} \mathrm{~S}_{i}>$ such that some aspect of $\mathrm{F}_{i}$ or some aspect of $\mathrm{S}_{i}$ is not strictly predictable from C's component parts or from other previously established constructions" (Goldberg 1995: 4). 
metrię w układach proporcjonalnych. Jednostki te, co istotne zwłaszcza w obliczu konfrontacji z $C G$, mają charakter formalnie zróżnicowany: są to nie tylko tzw. „kontrastywne segmenty sylabiczne” (KSS, ang. „,contrastive syllabic segments" - CSS, por. Bogusławski 1978: 37 i n.), czyli - w nieco innej terminologii - jednostki „leksykalne”, tradycyjne wyrazy lub ich połączenia (w wypadku frazeologizmów), ale także jednostki-operacje (nie-KSS), czyli przekształcenia KSS-ów w inne KSS-y (por. Bogusławski 1978: 44 i n.); operacje mogą mieć wykładniki (znamiona) segmentalne, np. morfemowe, mogą też jednak takich wykładników nie posiadać (np. wzorce intonacyjne). Przykładowymi kompendiami tej różnorodności jednostek współczesnej polszczyzny, choć ograniczonymi ze zrozumiałych względów do zjawisk dotąd nienotowanych, są sondy słownikowe Bogusławskiego i współautorów (por. Bogusławski, Wawrzyńczyk, 1993; Bogusławski, Danielewiczowa 2005).

Podkreślić trzeba, że teorii tej od początku przyświeca idea redukcjonizmu, a więc zasada niemnożenia bytów, w tym wypadku jednostek i ich znaczeń, przez co fundamentalną rolę odgrywa w niej odróżnienie semantyki od pragmatyki. Dalej - dla uproszczenia - będę stosował skrót $G O$ w odniesieniu do całej koncepcji zdyscyplinowanego opisu języka autorstwa Bogusławskiego, obejmującej nie tylko wyłożone w: Bogusławski 1978 preliminaria gramatyki operacyjnej wraz z doktryną jednostek języka (Bogusławski 1976), ale także rozwijaną równolegle teorię semantyczną, z pojęciem ,językowej konwencji poznawczej" (JKP; zob. Bogusławski 1979, 1993) na czele oraz wyraźnym rozróżnieniem semantyki od pragmatyki (kodu językowego od działań językowych, por. Bogusławski 2008).

2. Zacznijmy od podobieństw między $C G$ i $G O$. Na czoło wysuwa się najbardziej charakterystyczna cecha obu koncepcji, to jest niedoktrynalne podejście do czegoś, co można najbardziej ogólnie nazwać „terminałami” czy „formatywami” zdaniowymi. Zarówno $C G$, jak i $G O$ tym różnią się od głównych teorii składniowych, czy to strukturalistycznych, czy generatywistycznych, że nie zakładają apriorycznie, iż zdania języka naturalnego budowane są z określonych, jednorodnych jednostek niższego rzędu, np. leksemów / morfemów. $G O$ bardzo wyraźnie przeciwstawia się pod tym względem generatywizmowi (por. Bogusławski 1978: 30-34), przyjmując, że takimi formatywami są faktyczne formalnie zróżnicowane wyrażenia językowe (a nie abstrakcyjne symbole czy nieucieleśnione 'pojęcia'), kładąc przy tym nacisk na prymarnie 
dźwiękową materię językową. W wypadku $C G$ - wobec jej różnorodności trudno o tak wyraźnie jednoznaczną diagnozę, ale generalnie przeważa tu również empirycznie motywowane założenie, że punktem wyjścia dla opisu gramatycznego są faktyczne użycia tekstowe (a usage-based system), z których wydobywa się namacalne formy powiązane konwencjonalnie z funkcją / znaczeniem, czyli „konstrukcje”.

W konsekwencji stwierdzenia różnorodności formalnej ,jednostek języka” $(G O)$ / „konstrukcji” $(C G)$ obie teorie podważają - choć w niejednakowym stopniu - słuszność tradycyjnego, modułowego podejścia do gramatyki jako składającej się z wyraźnie oddzielonych od siebie komponentów: fonologii, morfologii i składni; zaciera się też w nich granica między leksyką a gramatyką. Pamiętać jednak trzeba, że zupełnie inny wymiar miała wstrzemięźliwość ze strony $G O$ wobec doktrynalnej modułowości gramatyk generatywnych / strukturalnych lat siedemdziesiątych. Świadomości skomplikowania materii językowej towarzyszy tutaj bowiem skromny, acz wyraźny postulat metodologiczny, by opis uczynić zdyscyplinowanym, dokładnym, rzetelnym i konsekwentnym. Podobna obserwacja na temat różnorodności faktycznie podstawowych elementów języka (czyli „konstrukcji”) poczyniona dwadzieścia lat później umieszcza postulat odrzucenia modułowości opisu w kontekście rozpowszechnionej już szeroko kognitywistycznej idei o „kontynualnym” w istocie charakterze języka i konieczności odrzucenia wszelkich ostrych granic w jego obrębie. Nie dziwi więc, że ,antymodułowość" CG jest umieszczana na sztandarach, zwłaszcza w jej kognitywistycznych nurtach, oddalonych od opisu języka w duchu generatywnym (najbliższe historycznie ducha generatywnego są prace Fillmore'a z okresu późnych lat osiemdziesiątych (por. Fillmore 1988), które uznaje się za swoistą klasykę $C G$ - tzw. Berkeley Construction Grammar, por. Hoffmann, Trousdale 2013).

Trzeba przyznać, że nie sposób odmówić - z perspektywy $G O$ przynajmniej częściowej - słuszności twierdzeniom $C G$ w rodzaju: „znajomość (składni) danego języka sprowadza się do znajomości pokaźnego zbioru konstrukcji-frazeologizmów” (Taylor 2007: 463) lub też: ,gramatyka staje się bowiem nie tyle dziedziną ogólnych reguł i zasad, ile olbrzymim zbiorem dość szczegółowych faktów powiązanych ze sobą za pomocą schematów o różnym stopniu ogólności” (Taylor 2007: 669). Bo też taki jest język - jego elementy podstawowe, jednostki, czyli to, co jest przyswajane w całości przez użytkowników i służy im jako budulec do konstruowania wypowiedzeń, ma 
$\mathrm{w}$ istocie charakter formalnie różnorodny, a klasyczne ujęcia JĘZYK $=$ LEKSYKON + GRAMATYKA ten obraz zaciemniają.

Zatem mamy z jednej strony wspólną i słuszną obserwację empiryczną o różnorodności formalnej elementów (jednostek / konstrukcji) języka, dającą podstawy do wysuwania w miarę zbieżnych hipotez szczegółowych lub nawet ogólniejszych, z drugiej zaś strony trzeba mieć na uwadze, że wnioski wyprowadzane z tychże hipotez przez $G O$ i $C G$ mogą być całkiem odmienne.

W wypadku $G O$ z zatarcia granic między leksykonem a gramatyką (a także między modułami wewnątrz gramatyki) nie czyni się wartości jako takiej, wpisując ją w doktrynę nieostrych granic i języka jako continuum. Zauważa się po prostu fakt, że gramatyka tkwi w jednostkach systemu, a nie jest nad nimi nadbudowana jako byt od tych jednostek niezależny. Najbanalniejszy przepis na zdanie w duchu wczesnego generatywizmu $(\Sigma \rightarrow \mathrm{NP}+\mathrm{VP})$ zadziała tylko wobec konkretnych, wskazanych jako klasa (semantyczna!) jednostek. Z tym problemem zresztą mierzyli się generatywiści niemal od początków doktryny, co zaowocowało włączeniem do gramatyki „komponentu semantycznego" wraz z leksykonem. Złudzeniem okazało się przekonanie, iż można zbudować normalne (sensowne) zdanie danego języka, dodając do dowolnej odpowiednio formalnie ukształtowanej NP dowolną odpowiednio formalnie ukształtowaną VP, czyli np. w języku fleksyjnym przypadkowym, jakim jest polski, łącząc dowolny rzeczownik w mianowniku z odpowiednią dla niego formą dowolnego czasownika. Będzie to wprawdzie jakiś model gramatyki (składni), ale tylko zaledwie w przybliżeniu oddający funkcjonowanie języka (w tym wypadku polskiego). Materia językowa jest bardziej skomplikowana, a przede wszystkim spiętrzona i rozwarstwiona - GO tylko postuluje, by odpowiednio uhonorować ten fakt, uwzględniając w opisie wszystkie istotne szczegóły.

3. Różnice między $G O$ a $C G$ widoczne w postrzeganiu relacji między leksykonem a gramatyka, które można by ostatecznie jakoś przezwyciężyć (np. uznać, że dla kognitywistycznych nurtów $C G$ to postrzeganie ma głównie walor retoryczny, jako kolejny dowód na kontynualność języka) pogłębiają się drastycznie, gdy przejdziemy do kolejnych „poziomów”, mianowicie semantyki i pragmatyki. Ujmowanie tych domen, a zwłaszcza opozycji między nimi, związane jest przede wszystkim z odmiennymi celami i zadaniami stawianymi przed gramatyką (lub szerzej: opisem języka). Kognitywistycz- 
nie zorientowane nurty $C G$ programowo tę opozycję neutralizują, w pozostałych nurtach (np. tych o bardziej sformalizowanej orientacji) opozycja ta również przestaje mieć znaczenie, choć z powodów mniej doktrynalnych, raczej $\mathrm{z}$ racji nastawienia na cele inne niż rekonstrukcja / opis systemu językowego. Cele nurtów różnych $C G \mathrm{w}$ szczegółach bywają definiowane rozmaicie - interpretacja faktów językowo-tekstowych może być umieszczana w kontekście opisu aktywności poznawczej mówiących (mówienie, poznawanie, przyswajanie języka itd.), modelowania zachowań komunikacyjnych lub innych, specyficznie określanych ramach (np. formalnie zorientowany nurt Fluid $C G$ gramatykę traktuje jako model rozwiązywania problemów, por. „...grammar is implemented as a problem-solving model rather than as a generative competence model", van Trijp 2015: 613). Kluczową rolę we wszystkich nurtach odgrywa przywołana wcześniej zasada uzualno-empiryczna, która nie tylko nakazuje wydobywać konstrukcje z rzeczywistych użyć (w tym nie różniłaby się wcale od $G O$ ), ale każe wprost wszystkie fakty związane z zachowaniami językowymi traktować identycznie. Idzie bowiem o „...wyjaśnienie wszystkich faktów obserwowanych w rzeczywistych danych językowych za pomocą tego samego aparatu teoretycznego" (Fried, Östman 2004: 24; Goldberg 2006: 64; cyt. za: Szymańska 2013: 136).

Gdy weźmie się jeszcze pod uwagę swoistą otwartość definicji konstrukcji Goldberg, gdzie mowa o niedookreślonych „pewnych aspektach” formy lub znaczenia, okaże się, że te „,aspekty” obejmują bardzo szeroko ujęte własności, por. np.: „W opisie konstrukcji forma może obejmować własności fonetyczne, morfologiczne i/lub składniowe, a znaczenie/funkcja - semantyczne, pragmatyczne i/lub dyskursowe" (Szymańska 2013: 135); por. też Fried, Östman 2005: 1753-1754). W późniejszych ujęciach Goldberg (por. Goldberg 2006: 5) wprost osłabione zostaje również ważne kryterium nieprzewidywalności sensu konstrukcji, bo jako „konstrukcje” są traktowane także wzorce całkiem przewidywalne (rozkładalne), jeśli są odpowiednio często używane. Natomiast najbardziej jawnie antyredukcjonistyczne są ujęcia kognitywne (Cognitive CG) oraz radykalne (Radical $C G$ ) - tam już nie będzie przesadą powiedzieć, że „wszystko jest konstrukcją” (por. Croft 2013, por. też Hoffmann, Trousdale, 2013) ${ }^{3}$.

3 Por. np.: „....all grammatical categories are language-specific and constructionspecific, RCG [Radical Construction Grammar] assumes no formal syntactic structure 
Niezależnie więc od różnic w szczegółach rozmaitych nurtów w $C G$ całkiem skutecznie zneutralizowana zostaje opozycja między językiem-systemem jako narzędziem a jego użyciem ${ }^{4}$. I w tym właśnie tkwi najistotniejsza różnica między podejściami nurtu $C G$ a metodą określoną tu skrótowo jako $G O$.

4. Przejdźmy teraz do konkretnych przykładów, a więc w naszym wypadku konstrukcji powtórzeniowych. Większość prac z uwagą odnotowuje oparte na repetycji konstrukcje, które spełniają także wymogi definicyjne operacyjnej jednostki języka w ujęciu Bogusławskiego GO. Są jednak takie, w których jako równoprawne gotowe całości przyswajane przez użytkowników języka traktuje się układy odczytywane na ogólniejszych zasadach. Jedyną cechą odróżniającą tych układów zdaje się być ich osobliwość wynikająca z samego faktu powtarzania (który pragmatycznie jest rzeczywiście często nacechowany). W ten sposób właśnie nie odróżnia się ciągów wyrażeń, które rozumie się na podstawie składników i ogólniejszej operacji / konstrukcji, od bytów, które są rzeczywistymi całostkami stanowiącymi budulec tworzenia zdań, czyli po prostu jednostkami (,konstrukcjami”) systemu językowego.

4.1. Do takich należy część tzw. quasi-tautologii, a zwłaszcza tzw. nominalne quasi-tautologie języka angielskiego - przykładem ich analizy będzie propozycja A. Wierzbickiej (1987) ${ }^{5}$. Nie będę tutaj relacjonował interpretacji ani argumentacji przedstawionej przez autorkę (szczegółowa relacja i dyskusja ze stanowiskiem Wierzbickiej znajduje się w pracy: Dobaczew-

other than the part-whole structure of constructions and the grammatical roles that occur in constructions. RCG is thus a nonreductionist theory that takes constructions to be holistic gestalt phenomena (in which part-part relationships play no role)" (Hoffmann, Trousdale, 2013: 7).

${ }^{4}$ Nawet jeśli w deklaracjach teoretycznych ta opozycja jest zachowana (por. Szymańska 2013), najczęściej w postaci pary pojęć construction vs construct (por. np. Fried, Östman 2004: 18; Goldberg 2006: 10), to praktyka badawcza nie pozostawia złudzeń wśród prac w duchu $C G$ na temat powtórzeń nie spotkałem żadnej, która zawierałaby choć jedną konkluzję negatywną (np. że jakiś brany pod uwagę schemat powtórzeniowy osobną „konstrukcją” nie jest, bo np. da się odczytać na ogólniejszych zasadach).

${ }^{5}$ Cytowana praca Wierzbickiej (1987) pochodzi oczywiście sprzed okresu rozkwitu $C G$, sama autorka też nigdy się z tym nurtem nie identyfikowała. Jednak - co ciekawe Wierzbickiej diagnoza tautologii angielskich została potraktowana jako przykład analizy konstrukcji w cytowanym tu już podręczniku oksfordzkim (Hoffmann, Trousdale, red. 2013), zob. Wullf 2013. 
ski 2018: 144-152), najistotniejsze dla nas w tej chwili jest to, że przeciwstawiając Grice'owskim interpretacjom zdań tautologicznych w rodzaju Women are women podejście - jak je sama nazwała - „radykalnie semantyczne”, Wierzbicka doskonale wręcz wpisuje się w antyredukcjonistyczny nurt $C G$ z wszystkimi tego konsekwencjami. Badaczka nie tylko widzi konieczność odnotowania schematów tautologicznych jako czegoś odrębnego, specyficznego dla angielszczyzny i wyposażonego w osobne ,znaczenia”, ale przewiduje cały zestaw schematów (konstrukcji) i ich znaczeń ${ }^{6}$.

Konsekwencją takiego podejścia jest nie tylko mnożenie bytów (jednostek / konstrukcji i ich znaczeń). Efektem poznawczo szkodliwym jest to, że quasi-tautologie typu Women are women zostają potraktowane jako zjawisko dokładnie tego samego poziomu, co np. polskie układy Co fachowiec, to fachowiec lub Sąd sądem, a... Tymczasem jest tutaj właśnie bardzo istotna różnica: angielskie zdanie Women are women można zrozumieć opierając się na tym samym sensie wyrażeń / konstrukcji are_i women, który znamy z innych wystąpień (np. Women are smart lub They are women). Co więcej, podobnie można budować takie quasi-tautologie w innych językach (po polsku będzie to np. Kobiety to kobiety) ${ }^{7}$. Natomiast układy typu Co fachowiec, to fachowiec reprezentują faktycznie specjalną jednostkę operacyjną (albo - jeśli ktoś woli - konstrukcję) języka polskiego, w której powtórzenie elementu nominalnego jest obligatoryjne, a próby ewentualnego zestawienia z układem typu Co fachowiec, to opinia pokażą, że nie ma między nimi symetrii.

4.2. Kolejnym przykładem niech będzie interpretacja powtórzeń w układach syndetycznych (typu Pada i pada) i asyndetycznych (typu Daw-

${ }^{6}$ Wierzbicka (1987: 104 i n.) zaproponowała wyodrębnienie sześciu produktywnych wzorców opartych na formule $(A R T) N_{i}$ be $(A R T) N_{i}$, z których każdy powinien być poddany gruntownej analizie, w efekcie której zostanie przypisana mu odpowiednia „eksplikacja” zdająca sprawę z zakodowanego w nim konwencjonalnie znaczenia (lub znaczeń), por.: (1) $N_{a b s t r}$ is $N_{a b s t r^{\prime}}$ (War is war); (2) $N_{p l}$ are $N_{p l}$. (Kids are kids); (3) $N_{p l}$ will be $N_{p l}$. (Boys will be boys); (4) An $N$ is an N. (A party is a party); (5) The $N$ is the $N$. (The law is the law); (6) $N_{1}$ is $N_{1}$ (and $N_{2}$ is $N_{2}$ ). (East is East, and West is West) (Wierzbicka 1987: 104).

7 Zdania takie w myśl wykładni wyrażenia _to (jest)_zaproponowanej przez Bogusławskiego (2000) czyta się mniej więcej jako ‘o kobietach coś wiadomo’. Natomiast problem międzyjęzykowej przekładalności quasi-tautologii jest w szczegółach bardziej skomplikowany, bo np. po polsku można też powiedzieć Kobiety są kobietami. Ale nie ma to nic wspólnego z suponowaną specyfiką quasi-tautologii ani angielskich, ani polskich, tylko różnicą pomiędzy ang. $\mathrm{N}$ is/are $\mathrm{N}$, pol. $\mathrm{N}_{\text {nom }}$ to (jest) $\mathrm{N}_{\text {nom }}$ i pol. $\mathrm{N}_{\text {nom }}$ jest $\mathrm{N}_{\text {instr }}$. Więcej na ten temat w: Dobaczewski 2018: 156-164. 
no, dawno temu). Jeden z głównych przedstawicieli nurtu $C G$, A. Stefanowitsch (jest jednym z autorów cytowanego tu oksfordzkiego podręcznika $C G$, por. Hoffmann, Trousdale (red.) 2013), analizując materiał niemiecki i angielski (por. Stefanowitsch 2007), wyróżnia te dwa schematy i znaczenia syndetycznej oraz asyndetycznej duplikacji. Pierwszy - $\left[\mathrm{W}_{\alpha}\right.$ und $\left.\mathrm{W}_{\alpha}\right]-\mathrm{z}$ interpretacją „Andauernder Prozess”, drugi - $\left[\mathrm{W}_{\alpha} \mathrm{W}_{\alpha}\right]$ - odczytany jako „Emphase/Intensivierung" (Stefanowitsch 2007: 41). Znaczenia obu konstrukcji traktuje jako całkowicie arbitralne, twierdząc, że nie da się wskazać motywacji dla procesualnego odczytania syndetonu ani intensyfikującej interpretacji asyndetonu.

Zacznijmy od konstrukcji repetycyjno-syndetycznej. Wbrew temu, co twierdzi Stefanowitsch, motywacja jest tu bardzo wyraźna - ćwierć wieku wcześniej Kuiper (1982) wskazywał, że znaczenia układu typu He walked, walked, and walked odczytuje zgodnie $\mathrm{z}$ sensem odpowiednich wyrażeń tworzących szereg. Z tego powodu - jak można sądzić - powtórzenia wokół spójnika łącznego (niem. und, ang. and, pol. $i$ itd.) odczytuje się podobnie jako komunikujące trwanie stanu rzeczy - w różnych językach ${ }^{8}$.

W podobnym jak u Stefanowitscha (2007) kierunku zmierzają interpretacje powtórzeń wokół $i$ w języku rosyjskim. Np. Sannikov (2008: 373-378) odnotowuje „konstrukcje” typu $О$ н рос и рос obok układów w rodzaju Идет, переваливается. Ну, утка и утка. oraz jeszcze innych typu Дорога плохая... Упал он. (Ну), упал и упал... Встал и дальше пошел. Na przykładzie rosyjskiego widać z całą wyrazistością, jak równoprawne, jednakowe traktowanie wszystkich wskazanych typów zaciemnia obraz języka. Zwróćmy uwagę, że dwa ostatnie typy powtórzeń wokół ros. spójnika $i$ to rzeczywiście specyficzne konstrukcje rosyjskie, wyspecjalizowane w repetycji, które nie mają analogonów nawet w spokrewnionym języku polskim (утка и утка to mniej więcej '(jak) prawdziwa kaczka', а упал и упал mоżna by przybliżyć za pomocą sformułowań no cóż - upadt (to upadt, nieważne) ${ }^{9}$. Natomiast $\mathrm{OH}_{H}$ poc u poc można zrozumieć, odwołując się do sensu spójnika i powtórzonego czasownika, a także oddać za pomocą analogicznej frazy polskiej, angiel-

${ }^{8}$ Całkowicie potwierdza to dokładna analiza semantyczna spójnika łącznego $i$ zaproponowana przez J. Wajszczuk 1997. Więcej szczegółów interpretacyjnych na temat tych układów znajduje się w cytowanej tu już pracy Dobaczewski 2018: 86-100.

9 Sannikov (2008: 378) znaczenie tego typu konstrukcji charakteryzuje jako wyraz nieprzywiązywania nadmiernej wagi do (zasadniczo niepożądanego) zdarzenia. 
skiej, niemieckiej itd. Powtórzenia wokół słówka $i$ reprezentują więc w powyższych wypadkach całkiem odmienne kategorie zjawisk.

Jest jasne, że kluczową rolę w odróżnianiu rzeczywistych jednostek, czyli tego, co nierozkładalne (nieprzewidywalne) odgrywa proporcja analogiczna z symetrią ładunku semantycznego. Trzeba też przyznać, że koniecznym warunkiem zaobserwowania takiej symetrii jest przyjęcie (jakiejś) redukcjonistycznej koncepcji znaczenia. Bo przy charakterystycznym dla części prac nurtu $C G$ (i cytowanej wcześniej Wierzbickiej) antyredukcjonizmie (acz nie zawsze zadeklarowanym), z którego wynika jednakowe traktowanie wszelkich opozycji funkcjonalnych, tak semantycznych, jak i pragmatycznych, w szczególności opartych na impresjach i dodatkowych interpretacjach wydobywanych $\mathrm{z}$ kontekstu (w tym np. osobliwego kontekstu repetycyjnego, który zaws ze zwraca jakoś na siebie uwagę), zastosowanie opartego na proporcji mechanizmu odróżniającego konstrukcje będące faktycznymi jednostkami systemu od rozmaitych kombinacji i złożeń przewidywalnych, staje się - jak widać z cytowanych prac - niewykonalne (nawet mimo teoretycznie przyjmowanej opozycji konstrukcja-konstrukt $)^{10}$.

4.3. Zatrzymajmy się teraz przez chwilę na drugim z opisywanych przez Stefanowitscha (2007) typów repetycji, mianowicie bezspójnikowej „konstrukcji wzmacniającej”. Stanowi ona rzeczywiście pewne wyzwanie, bo w przeciwieństwie do układów spójnikowych, a także omawianych wcześniej quasi-tautologii, nie wpisuje się wcale w żaden ogólniejszy schemat składniowy nierepetycyjny, z którym można byłoby ją zestawić, by sprawdzić, czy nie reprezentuje szczególnego wypadku identycznego wypełnienia pozycji $(x F x)$ przewidzianych zasadniczo dla elementów różnych $(x F y)$. Zauważmy jednak najpierw, że konkluzja w postaci „powołania” specjalnej konstrukcji (np. angielskiej typu a long, long letter czy niem. typu scharfes scharfes Messer, por. też: dlugi, dlugi list i ostry, ostry nóż) jest kontrintuicyjna w obliczu

10 Trzeba uczciwie zaznaczyć, że nie wszystkie prace z nurtu $C G$ poświęcone powtórzeniom lekceważą proporcjonalność jako test na wielość funkcji / znaczeń. Zdecydowanie bardziej zdyscyplinowane podejście widać np. u Jackendoffa (2008), który sprawdzając różne konteksty przyimków, właśnie wykazuje odrębność badanych przez siebie konstrukcji - nominalnych powtórzeń wokółprzyimkowych $N p N$ (np. day after day). Choć tutaj sens całości także daje się odczytać ze składników (a w konsekwencji przetłumaczyć, por. np. dzień za dniem), to jednak na rzecz osobnego potraktowania takich konstrukcji przemawiają względy składniowe (por. Dobaczewski 2018: 246-252). 
jej swobodnej przekładalności, być może nawet uniwersalności. Poza tym widać uderzający kontrast między faktycznymi, występującymi w różnych językach reduplikacjami tzw. całkowitymi (obejmującymi całe morfemy lub słowa), obarczonymi istotnymi funkcjami gramatycznymi i semantycznymi, ewidentnie skonwencjonalizowanymi a tym zjawiskiem powtarzania słów, którego „emfatyczna” interpretacja ma znamiona ikonicznie motywowanego ponadjęzykowego, być może uniwersalnego sposobu mówienia ${ }^{11}$.

$\mathrm{Na}$ dokładną diagnozę powtórzeń ,emfatycznych” nie ma tu miejsca (szczegóły zostały przedstawione w Dobaczewski 2018: 56-70), trzeba jednak podkreślić, że gdy weźmie się pod uwagę istotną dla $G O$ opozycję kodu vs działania językowego (opartą na de Saussure'owskiej opozycji langue parole, por. też kluczową dla generatywizmu parę competence - performance), a ponadto przyjmie się (za Bogusławskim, 2008) ogólne założenie, że rzeczywiste zachowania językowe w niejednakowym stopniu odzwierciedlają kod językowy ${ }^{12}$, to można w świetle przytoczonych wyżej obserwacji wysunąć przypuszczenie, iż powtórzenie „emfatyczne” jest w istocie pozakodowym (retardacyjnie naruszającym porządek składniowy) zachowaniem ponadjęzykowym, podobnie jak (nieco inaczej motywowane, ale oparte na tym samym mechanizmie ,,antyskładniowym”) powtórzenia o funkcji rytmizującej.

11 Podobne funkcje intensyfikujące lub emfatyczne powtórzeń występują także w tych językach, które systemowo korzystają z mechanizmów reduplikacji, w tym tzw. reduplikacji składniowej, czyli podwajania całych słów. Oprócz języków egzotycznych są to języki południa Europy (sporo przykładów zebranych jest w pracy Stolz et al. 2011). Przypuszczenie o uniwersalności zjawiska powtarzania modyfikatora wyraziła wcześniej E. Moravcsik, por.: ,[...] it is perhaps true in all languages that an emphatic modifier (such as very) can be open-endedly reduplicated for additional emphasis" (Moravcsik 1978: 312).

12 Tu także widać pewną zbieżność między $G O$ a $C G$-mam na myśli potencjał tkwiący w pojęciu koercji (lub „stretchingu”) i użyciach „nielicencjonowanych” (por. Szymańska 2013). W CG jednak rzecz jest znowu najczęściej rozmyta w kontynualnej (dynamicznej) przestrzeni między systemem a użyciem, natomiast w ujęciu Bogusławskiego mamy wyraźnie zaakcentowaną ostrość ontologiczną: wszelkie użycia ponadpodstawowe, „naciągane”, niebędące prostym odzwierciedleniem kodu są świadectwem natury ludzkiego działania; są cechą tegoż użycia, a nie istotną i konstytutywną cechą systemu językowego. 
5. Niezależnie od przyjęcia takich czy innych rozwiązań szczegółowych w kwestiach opisu quasi-tautologii i powtórzeń sygnalizowanych wyżej, można skłonić się ku następującej konkluzji. Ujęcia proponowane w nurtach $C G$ lub z nimi związane prowadzą do wyodrębniania coraz to kolejnych „konstrukcji”, powiększając ich repertuar widziany jako zbiór zjawisk tego samego poziomu i tej samej natury, nie dając możliwości pokazania - istotnych być może z punktu widzenia funkcjonowania języka - różnic między nimi. Natomiast koncepcja Bogusławskiego, oznaczona tu jako GO, oparta na zasadniczej idei proporcjonalności w języku oraz opozycji język (kod) $v s$ działanie językowe, daje narzędzia umożliwiające efektywne rozróżnianie w obrębie konstrukcji powtórzeniowych 1) rzeczywistych operacyjnych jednostek danego języka; 2) przewidywalnych i zrozumiałych na ogólnych zasadach połączeń z tautologicznie wypełnianymi pozycjami przewidzianymi zasadniczo dla elementów różnych oraz 3) powtórzeń będących wynikiem ogólniejszych, być może ponadjęzykowych reguł działania mownego.

$\mathrm{Na}$ koniec wypada zastrzec jeszcze raz, że pobieżne uwagi poczynione w tym artykule nie pretendują - rzecz jasna - do roli rzetelnej, krytycznej analizy koncepcji opisu języka, jakimi są różne odmiany nurtu $C G$. Są to raczej refleksje nad praktyką badawczą, i to bardzo wąsko wykrojoną - prace o powtórzeniach to przecież kropla w oceanie rozpraw tego nurtu. Ale pokazują zawarte tu obserwacje, że starsza o kilkanaście lat koncepcja $G O$ Bogusławskiego widziała wcześniej zjawiska „odkrywane” przez $C G$, a nadto widzi je nadal nieco ostrzej. Więc gdybyśmy mieli porównać przedstawione tutaj pokrótce podejścia całkiem niedoktrynalnie, to pierwszeństwo trzeba by oddać tej metodzie, która pozwala wprowadzać rozróżnienia niezauważane przez inną metodę, tym bardziej że rozróżnienia te nie mają charakteru przygodnych ani nieistotnych.

\section{Bibliografia}

Apresjan Ju. D., Boguslavskij I. M., Iomdin L. L., Sannikov V. Z., 2010 / AпPEСЯН Ю. Д., БоГУСЛАвСКИй И. М., ИомдИН Л. Л., САНников В. 3., 2010, Теоретические проблемы русского синтаксиса. Взаимодействие грамматики и словаря, Москва: Языки славянских культур.

BogusŁawski A., 1976, O zasadach rejestracji jednostek języka, Poradnik Językowy 8, s. 356-364. 
BogusŁawski A., 1978, Towards an operational grammar, Studia Semiotyczne VIII, s. 29-90 (polski przekład: Bogusławski 1988, tłum. R. Gozdawa-Gołębiowski).

BogusŁawski A., 1979, Performatives or metatextual comments? On the cognitive and non-cognitive linguistic conventions, Kwartalnik Neofilologiczny 26, 3, s. 301-326.

Bogusıawski A., 1988, Preliminaria gramatyki operacyjnej, Polonica 13, s. 163-223.

BogusŁawski A., 1993, „Znaczenie” a ,,językowa konwencja poznawcza”, w: J. Bartmiński, R. Tokarski (red.), O definicjach i definiowaniu, Lublin: Wydawnictwo UMCS, s. 83-100.

BogusŁaWski A., 2001, Glosa do kontrowersji wokół działań na quasi-tautologiach, w: G. Habrajska (red.), Język w komunikacji, t. 1, Łódź: Wyższa Szkoła Humanistyczno-Ekonomiczna, s. 53-58.

BogusŁaWski A., 2008, Semantyka, pragmatyka. Leksykografa głos demarkacyjny, Warszawa: Takt.

BogusŁawski A., Danielewiczowa M., 2005, Verba polona abscondita. Sonda stownikowa III, Warszawa: Elma Books.

BogusŁawski A., Wawrzyńczyk J., 1993, Polszczyzna, jaka znamy. Nowa sonda stownikowa, Warszawa: Katedra Lingwistyki Formalnej UW.

Croft W., 2013, Radical Construction Grammar, w: T. Hoffmann, G. Trousdale (red.), The Oxford Handbook of Construction Grammar, Oxford: Oxford University Press, [online:] doi: 10.1093/oxfordhb/9780195396683.013.0012.

DobaczewsKi A., 2018, Powtórzenie jako zjawisko tekstowe i systemowe. Repetycje, reduplikacje i quasi-tautologie w języku polskim, Toruń: Wydawnictwo Naukowe UMK.

Fillmore C. J., 1988, The mechanisms of Construction Grammar, Proceedings of the Annual Meetings of Berkeley Linguistics Society 14, s. 35-55.

Fried M., Östman J. O., 2004, Construction Grammar: a thumbnail sketch, w: M. Fried, J. O. Östman (red.), Construction Grammar in a cross-language perspective, Amsterdam: John Benjamins, s. 11-86.

Fried M., Östman J. O., 2005, Construction Grammar and spoken language: the case of pragmatic particles, Journal of Pragmatics 37(11), s. 1752-1778, [online:] doi: 10.1016/j.pragma.2005.03.013.

Goldberg A., 1995, Constructions: A Construction Grammar Approach to Argument Structure, Chicago: University of Chicago Press.

Goldberg A., 2006, Constructions at Work: The Nature of Generalization in Language, Oxford: Oxford University Press.

Hoffmann T., Trousdale G., 2013, Construction Grammar: Introduction, w: T. Hoffmann, G. Trousdale (red.), The Oxford Handbook of Construction Grammar, Oxford: Oxford University Press, s. 1-13. 
Iomdin L. L., 2006 / Иомдин Л. Л., 2006, Многозначные синтаксические фраземы: между лексикой а синтаксисом, Компьютерная лингвистика и интеллектуальные технологии 5, s. 202-206.

JACKENDOFF R., 2008, 'Construction after construction' and its theoretical challenges, Language 84 (1), s. 8-28.

Kopotev M. V., 2008 / Копотев М. В., 2008, Принципь синтаксической идиоматизации, Хельсинки / Helsinki: University Press.

KUIPER K., 1982, Once more with feeling: modifier repetition as a stylistic rule, Linguistics 20, s. 493-517.

Moravcsik E., 1978, Reduplicative constructions, w: J. H. Greenberg (red.), Universals of Human Language, vol. III: Word Structure, Standford: Standford University Press, s. 297-334.

Rachilina E. V., 2010 / РАхилина Е. В., 2010, Лингвистика конструкциии, Москва: Азбуковник.

Sannikov V. Z., 2008 / Санников B. 3., 2008, Русский синтаксис в семантикопрагматическом пространстве, Москва: Языки славянских культур.

Stefanowitsch A., 2007, Wortwiederholung im Englischen und Deutschen: eine korpuslinguistische Annäherung, w: A. Ammann, A. Urdze (red.), Wiederholung, Parallelismus, Reduplikation. Strategien der multiplen Strukturanwendung, Bochum: Universitätsverlag Brockmeyer, s. 29-45.

Stolz T., Stroh C., Urdze A., 2011, Total Reduplication. The Areal Linguistics of a Potential Universal, Berlin: Akademie-Verlag.

SzYmańska I., 2013, Relacje między systemem językowym i jego realizacjami w gramatyce konstrukcji, Linguistica Copernicana 10 (20), s. 133-145, [online:] doi: 10.12775/LinCop.2013.025.

TAYLOR J. R., 2007, Gramatyka kognitywna, Kraków: Universitas.

van TRIJP R., 2015, Cognitive vs generative construction grammar: The case of coertion and argument structure, Cognitive Linguistics, 26 (4), s. 613-632.

WajszczuK J., 1997, System znaczeń w obszarze spójników polskich. Wprowadzenie do opisu, Warszawa: Katedra Lingwistyki Formalnej UW.

WierzBicka A., 1987, Boys will be boys: 'radical semantics' vs. 'radical pragmatics', Language 63, 1, s. 95-114.

Wullf S., 2013, Words and idioms, w: T. Hoffmann, G. Trousdale (red.), The Oxford Handbook of Construction Grammar, Oxford: Oxford University Press, [online:] doi: 10.1093/oxfordhb/9780195396683.013.0015. 


\section{Operational grammar $v$ s. construction grammar (on the example of quasi-tautologies and repetitions)}

\section{( su m mary)}

In this article, the two linguistic approaches are confronted: the first is Construction Grammar, which has been intensively developed in recent years, mainly in cognitive linguistics, and is represented by numerous researchers of Polish, European, and world linguistics; the second is the less known, author's methodological proposal by Andrzej Bogusławski (the so-called Operational Grammar, presented in the article Bogusławski 1978). On the example of the description of selected types of repetitive constructions (of Polish and several other languages), significant differences in the effects of applying both research approaches are shown. The main thesis is the claim that, in contrast to the fashionable and willingly practiced CG, the Polish linguist's methodological proposal (OG), based on the fundamental idea of proportionality in language, does give tools to effectively distinguish amongst repetitive constructs: 1) the real operational units of a given language; 2) predictable and generally comprehensible constructs with tautologically filled items (intended essentially for different elements); and 3) repetitions resulting from more general, perhaps supra-linguistic rules of speech activity. Despite the diversity of the many currents of CG, it seems that it does not provide the tools to properly separate these three essentially different types of textual phenomena (and at least this is not indicated by the practice of research on repetitions influenced by $\mathrm{CG}$ ).

K e y w o r d s : quasi-tautology; repetition; construction grammar; operational grammar 